\title{
Physiological Changes of Torch Ginger (Etlingera elatior) Inflorescence during Development
}

\author{
Sea Yeat Choon and Phebe Ding ${ }^{1}$ \\ Department of Crop Science, Faculty of Agriculture, Universiti Putra \\ Malaysia, 43400 Serdang, Selangor, Malaysia
}

Additional index words. bract browning, carbohydrate depletion, soluble sugars, starch distribution, sympodial growth

\begin{abstract}
The present study was undertaken to reveal the developmentally regulated changes in physical and physiological characteristics of torch ginger (Etlingera elatior) inflorescence in relation to its usage as a cut flower. The inflorescences at four developmental stages, i.e., tight bud (TB), six reflexing tip (SRT), all involucral bracts unfolded (IBU), and full bloom (FB) were studied. The results revealed that the fresh and dry weights of inflorescences increased significantly from TB to FB stage. Water was the main component of inflorescence with $90.8 \%$ to $91.9 \%$ of the total mass. Thus, cell expansion resulting from water influx is crucial for inflorescence head development and bract opening. No ethylene was detected in the inflorescences at the four developmental stages. However, a significant higher respiration rate was recorded at FB stage with actively developing and opening true flowers in the inflorescence. The high respiration rate eventually leads to depletion of soluble sugars and starch grains in involucral bracts and inflorescence peduncle, respectively. Thereafter, involucral bracts showed browning and senescing. This result implies that the inflorescence head is a major sink for photoassimilates during flowering stage. Thus, soluble sugars exhaustion is expected to be a main factor of inflorescence senescence.
\end{abstract}

Torch ginger (E. elatior) is a perennial herbaceous clumping plant that belongs to the family Zingiberaceae. It can be propagated from seeds or rhizomes. A torch ginger plant consists of a leaf stalk (pseudostem) and an inflorescence borne on a separate leafless peduncle arising from the underground rhizome (Choon and Ding, 2016). The height of the leaf stalk is $\approx 3-4 \mathrm{~m}$ whereas the peduncle length is $\approx 0.7 \mathrm{~m}$. The torch ginger inflorescence is composed of involucral and floral bracts. The inflorescence bracts may be red, pink, or white (Choon et al., 2016). At FB stage, an inflorescence may contain 3-4 layers of involucral bracts, 20-25 layers of floral bracts, and 90 120 true flowers (Choon and Ding, 2016).

Commonly, the inflorescence bud is used as an aromatic spice for culinary purposes in Southeast Asia. In fact, the showy inflorescence at each developmental stage can also be used as cut flower. It has been used as floral arrangements in Australia, Brazil, Costa Rica, Thailand, and the United States (Carneiro et al., 2014; Loges et al., 2011; Prasongchan et al., 2009). However, to date, the characteristics of the inflorescence during the growth and development remained to be elucidated.

Previous phenological observation revealed that torch ginger plant demonstrated a sympodial growth pattern. The leaves yellowing of individual leaf stalk and browning on involucral

Received for publication 18 July 2016. Accepted for publication $25 \mathrm{Jan} .2017$.

${ }^{1}$ Corresponding author. E-mail: phebe@upm.edu. my.
Plant materials. Torch ginger inflorescences at the four developmental stages, i.e., a) TB (closed and pigmented bud), b)
SRT (six pieces of IBU), c) IBU, and d) FB (first ring of true flowers opened) (Fig. 1AD), at $\approx 35,45,58$, and $60 \mathrm{~d}$ after emergence aboveground, respectively, were used in this study. The inflorescences were harvested between 8:00 and 8:30 AM from Farm 2, Faculty of Agriculture, Universiti Putra Malaysia. The inflorescences were cut at the soil level. After harvesting, the inflorescences were placed in a clean bucket with tap water and transported to Laboratory of Postharvest, Faculty of Agriculture.

Fresh weight, dry weight, and water content. The harvested torch ginger inflorescences at the four developmental stages were weighed and determined as fresh weight of the inflorescence. Then, the inflorescence was oven-dried at $60^{\circ} \mathrm{C}$ until constant weight was achieved. The water content of the inflorescence $(\%)$ was calculated with the formula: $\{$ [fresh weight of inflorescence $(\mathrm{g})$ dry weight of inflorescence $(\mathrm{g})] /$ fresh weight of inflorescence $(\mathrm{g})\} \times 100 \%$.

Respiration and ethylene production rates. The concentrations of carbon dioxide $\left(\mathrm{CO}_{2}\right)$ and ethylene $\left(\mathrm{C}_{2} \mathrm{H}_{4}\right)$ produced by the inflorescences were determined using a static system. The individual inflorescence at the four developmental stages was wrapped with polyethylene bag, sealed, and incubated at $22{ }^{\circ} \mathrm{C}, 60 \%$ to $65 \%$, respectively, relative humidity and $5.5 \mu \mathrm{mol} \cdot \mathrm{m}^{-2} \cdot \mathrm{s}^{-1}$ of light intensity for $2 \mathrm{~h}$. Using a $1-\mathrm{mL}$ syringe, gas sample was withdrawn from the polyethylene bag fitted with silicone septa and injected into the sample injector port of a gas chromatography (Clarus 500; Perkin Elmer, Shelton, $\mathrm{CT}$ ). The measurement was repeated three times. The results were expressed as $\mathrm{mL}$ $\mathrm{CO}_{2} / \mathrm{kg} / \mathrm{h}$ and $\mathrm{nL} \mathrm{C}_{2} \mathrm{H}_{4} / \mathrm{kg} / \mathrm{h}$.

Soluble sugar content. In the present study, only involucral bracts were used for soluble sugar content determination as floral bracts of the inflorescence at TB and SRT stages were not fully developed. Three to four layers of involucral bracts collected from each inflorescence at the four developmental stages were ground in liquid nitrogen and stored at $-80{ }^{\circ} \mathrm{C}$ until analysis. Method of Sood et al. (2006) with modifications was used for bract tissue extraction. Bract tissues $(0.1 \mathrm{~g})$ were homogenized with $80 \%$ ethanol $(10 \mathrm{~mL})$. The homogenate was heated in a water bath (SBS40; Stuart, UK) at $80{ }^{\circ} \mathrm{C}$ for $5 \mathrm{~min}$ then centrifuged (1730R; ScanSpeed, Denmark) at $8000 g_{\mathrm{n}}$ for $15 \mathrm{~min}$. The

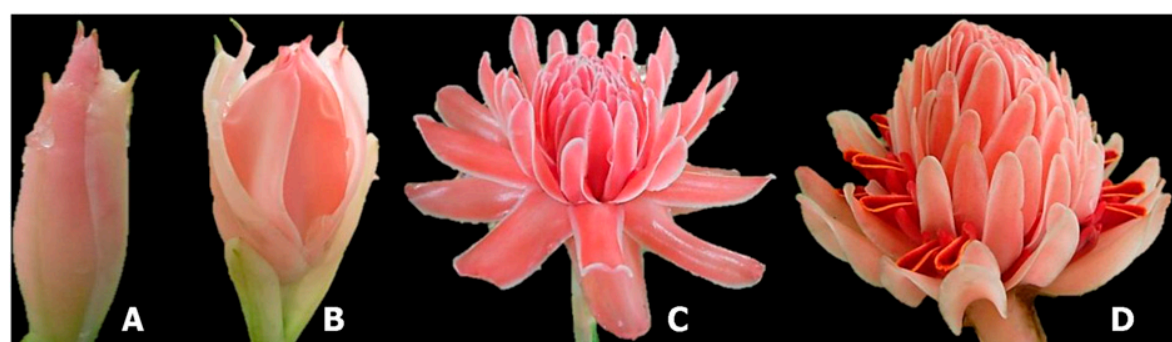

Fig. 1. The four developmental stages of torch ginger inflorescences used in this study: (A) tight bud, (B) six reflexing tip, (C) all involucral bracts unfolded, and (D) full bloom. 

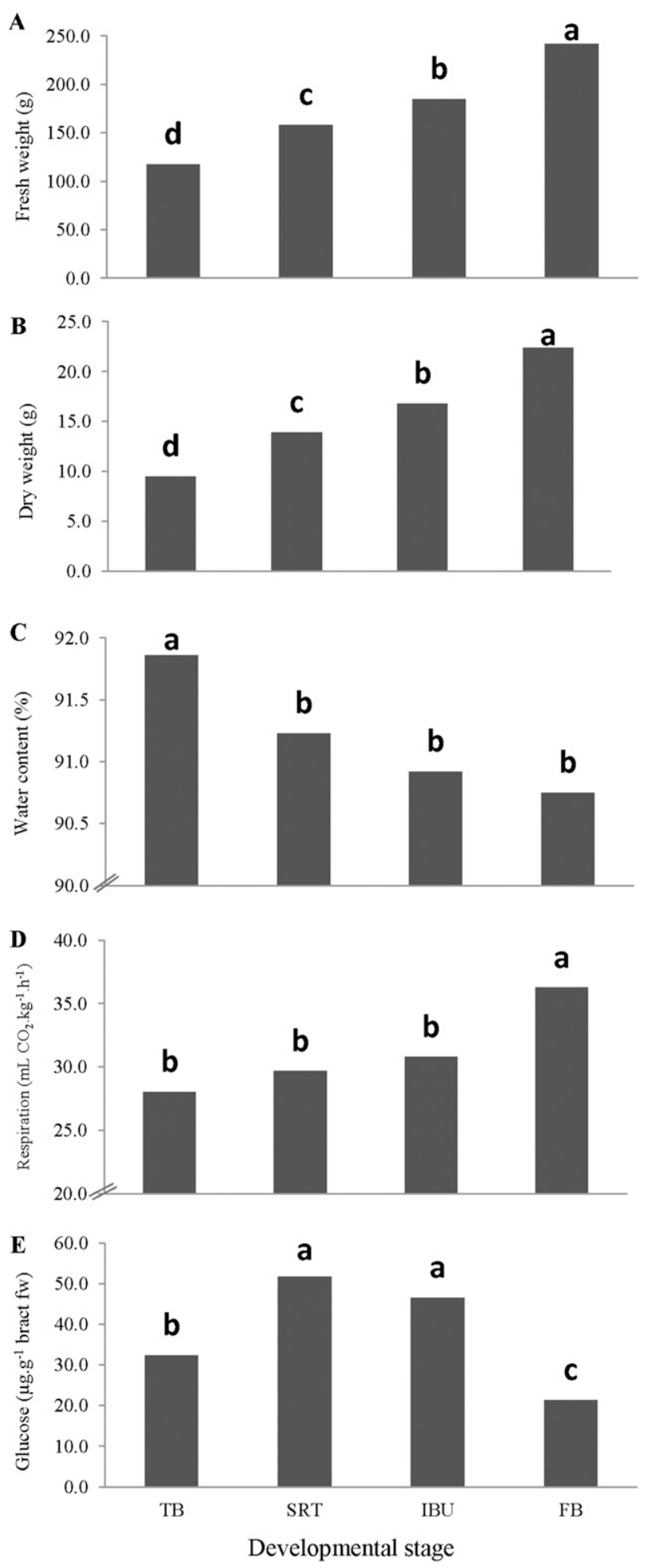

Fig. 2. Changes in (A) fresh weight, (B) dry weight, $(\mathbf{C})$ water content, $(\mathbf{D})$ respiration rate, and (E) soluble sugar content of torch ginger inflorescences at the four developmental stages. The soluble sugar content in involucral bracts was measured using glucose as standard. Developmental stages are described with abbreviations as follows: $\mathrm{TB}=$ tight bud; SRT $=$ six reflexing tip; IBU $=$ all involucral bracts unfolded $\mathrm{FB}=$ full bloom. Data are the means of three replications. Means followed by the different letters are significantly different by Duncan's multiple range tests at $P \leq 0.05$.

supernatant was collected and used for soluble sugar content analysis.

Soluble sugar content in involucral bracts was measured using anthrone reagent as described by Yemm and Willis (1954) with modifications. For analysis,
$0.2 \mathrm{~mL}$ of supernatant was added to $2 \mathrm{~mL}$ of anthrone reagent, vortexed, and incubated for $2 \mathrm{~min}$. The mixture was then heated in a boiling water bath for $10 \mathrm{~min}$ to start the reaction. The reaction was ended by keeping the mixture in ice-cold water for $5 \mathrm{~min}$. The absorbance of mixture was measured at $620 \mathrm{~nm}$ using a Spectrawave spectrophotometer (WPA S1200; Biochrom, UK). The measurement of soluble sugar content was repeated three times for each sample. A calibration curve was prepared using glucose as standard $\left(0.005-0.5 \mathrm{mg} \cdot \mathrm{mL}^{-1}, r^{2}=0.99\right)$ giving an absorbance range of $0.058-2.408$. The result was expressed as microgram glucose per gram bract fresh weight $(\mu \mathrm{g}$ glucose/g bract fw).

Tissue preparation for starch distribution in inflorescence peduncle. The upper $(3 \mathrm{~cm}$ beneath inflorescence head) and basal $(3 \mathrm{~cm}$ from soil surface) parts of five freshly harvested inflorescence peduncle at the four developmental stages were used. Transverse sections of the peduncle parts were cut (thickness $1 \mathrm{~mm}$ ) using freehand section technique with a razor blade. The sections were stained with iodine solution $\left(\mathrm{I}_{2} \mathrm{KI}\right)$ for $5 \mathrm{~min}$. Sections were examined using a compound microscope (Meiji Techno, Japan) equipped with a digital camera (Olympus, USA).

Experimental design and statistical analysis. Five individual inflorescences were used for each characteristic determination. The experiment was conducted three times. The data were analyzed by analysis of variance using SAS (Version 9.2; SAS Institute, Cary, NC). The means comparison was performed using Duncan's multiple range test at $5 \%$ significance level.

\section{Results}

Fresh weight, dry weight, and water content. The fresh weight of torch ginger inflorescences increased significantly from TB to FB stage (Fig. 2A). An increase of fresh weight by $34.9 \%$ was found in inflorescences at SRT stage compared with TB stage. The development of inflorescences from SRT to IBU stage caused an increase in fresh weight by $17 \%$. The highest fresh weight of inflorescences was recorded at FB stage, which was double the fresh weight of inflorescences at TB stage.

Similar to fresh weight, the dry weight of inflorescences also increased significantly from TB to FB stage (Fig. 2B). The dry weight measured in inflorescences at SRT stage was $46.3 \%$ higher than inflorescences at TB stage. The highest dry weight of inflorescences was recorded at FB stage, which was $61.2 \%$ and $33.3 \%$ higher than inflorescences at SRT and IBU, respectively.

Results indicated that the inflorescences at $\mathrm{TB}$ stage contained more water relative to their fresh weight compared with the inflorescences at SRT, IBU, and FB stages (Fig. 2C). However, there was no significant difference in water content measured in inflorescences at SRT, IBU, and FB stages.

Respiration and ethylene production rate. The continuous development of inflorescences from TB to IBU stage did not influence the respiration rate as there was no 
significant difference in respiration rate measured (Fig. 2D). However, as the inflorescences reached FB stage, the respiration rate recorded was higher than inflorescences at TB stage by $29.6 \%$. No ethylene was detected in the inflorescences at the four developmental stages studied. This may indicate that no ethylene was produced by the inflorescences or the concentration of the ethylene produced was below the detectable level.

Soluble sugar content. The soluble sugar content in involucral bracts increased by $59.6 \%$ from TB to SRT stage (Fig. 2E). The further development of the inflorescences from SRT to IBU stage had no prominent effect on soluble sugar content in involucral bracts. However, as the inflorescence reached FB stage, the soluble sugar content in involucral bracts decreased sharply by $54.0 \%$ compared with IBU stage, which also the lowest among the four developmental stages.

Starch grains distribution in peduncle. The distribution of iodine-stained starch grains in the peduncle varied with developmental stage, lengthwise location, and the heart zone. In this study, the results are shown for peduncles of the TB and $\mathrm{FB}$ stages (Fig. 3A and $\mathrm{B}$ ). The transverse section of the upper and basal parts of TB stage peduncle turned blue-black color after staining with $\mathrm{I}_{2} \mathrm{KI}$ indicated the presence of starch grains (Fig. 3C and E). The staining results revealed that at the upper part, starch grains were located at the outer heart zone (Fig. 3C), whereas at the basal part of peduncle, starch grains were found in the inner sheaths and outer heart zone (Fig. 3E).
In the outer heart zone, the starch density at the upper part of the TB stage peduncle was less than the basal part (Fig. 3D and F). The starch density in the outer heart zone of the upper and basal parts of peduncle decreased toward the inner heart zone. Starch grain was not noticed in the inner heart zone of both the upper and basal parts of the TB stage peduncle.

In the FB stage peduncle, the upper part section that stained with $\mathrm{I}_{2} \mathrm{KI}$ showed brown color (Fig. 3G). It was observed that scattered starch grains were found in the outer heart zone of the upper part peduncle (Fig. 3H). In the basal part, the starch density was low. It was noticed that the starch grains only accumulated in certain parts of the inner sheath and outer heart zone instead of being evenly distributed (Fig. 3I and J). As in the TB stage peduncle, no starch grain was found in the inner heart zone of both the upper and basal parts of the FB stage peduncle.

\section{Discussion}

During the growth and development of the torch ginger inflorescence, the maturation of the inflorescence is identified by the increase in the size of inflorescence head. Results showed that the fresh and dry weights of the inflorescences increased significantly as the developmental stage advanced from TB to FB. The water content measured in the inflorescences at the four developmental stages ranged from $90.8 \%$ to $91.9 \%$ of the total mass, which indicates that water is the main constituent of the inflorescence. Therefore, water influx for cell expansion is crucial for torch ginger inflorescence development.
In flower physiology, respiration rate has been used as an indicator of flower longevity (Reid, 1985). The flower with higher respiration rate tends to have shorter longevity (Gago and Monteiro, 2011). In torch ginger, the respiration rate of inflorescence was consistent during TB, SRT, and IBU stages. The constant respiration rate due to the inflorescence head development at these stages only involved the increase in bracts size and true flowers development (Fig. 1A-C). When the true flowers opened in inflorescence at FB stage (Fig. 1D), a significant higher respiration rate was recorded. The active growing and opening of true flowers ring by ring could be the reason for higher respiration rate in inflorescence at FB stage.

It was found that the higher respiration rate of inflorescence at FB stage coincided with the drastic decrease in soluble sugar content in involucral bracts and starch grains in peduncle of inflorescence at $\mathrm{FB}$ stage. Thereafter, the involucral bracts showed browning and senescing. The ethylene determination showed that no ethylene was detected in the inflorescence and the application of exogenous ethylene (50-400 $\left.\mu \mathrm{L} \cdot \mathrm{L}^{-1}\right)$ had no detrimental effects on inflorescence senescence (Choon and Ding, unpublished data). Hence, bract browning of inflorescence was not caused by an ethylene effect. The browning symptom could result from the soluble sugar content and starch grains depletion in involucral bracts and peduncle, respectively.

The result of iodine staining showed that starch grains in peduncle decreased from $\mathrm{TB}$ to FB stage and the density also decreased from the basal part to the upper part of peduncle. The intense staining of starch

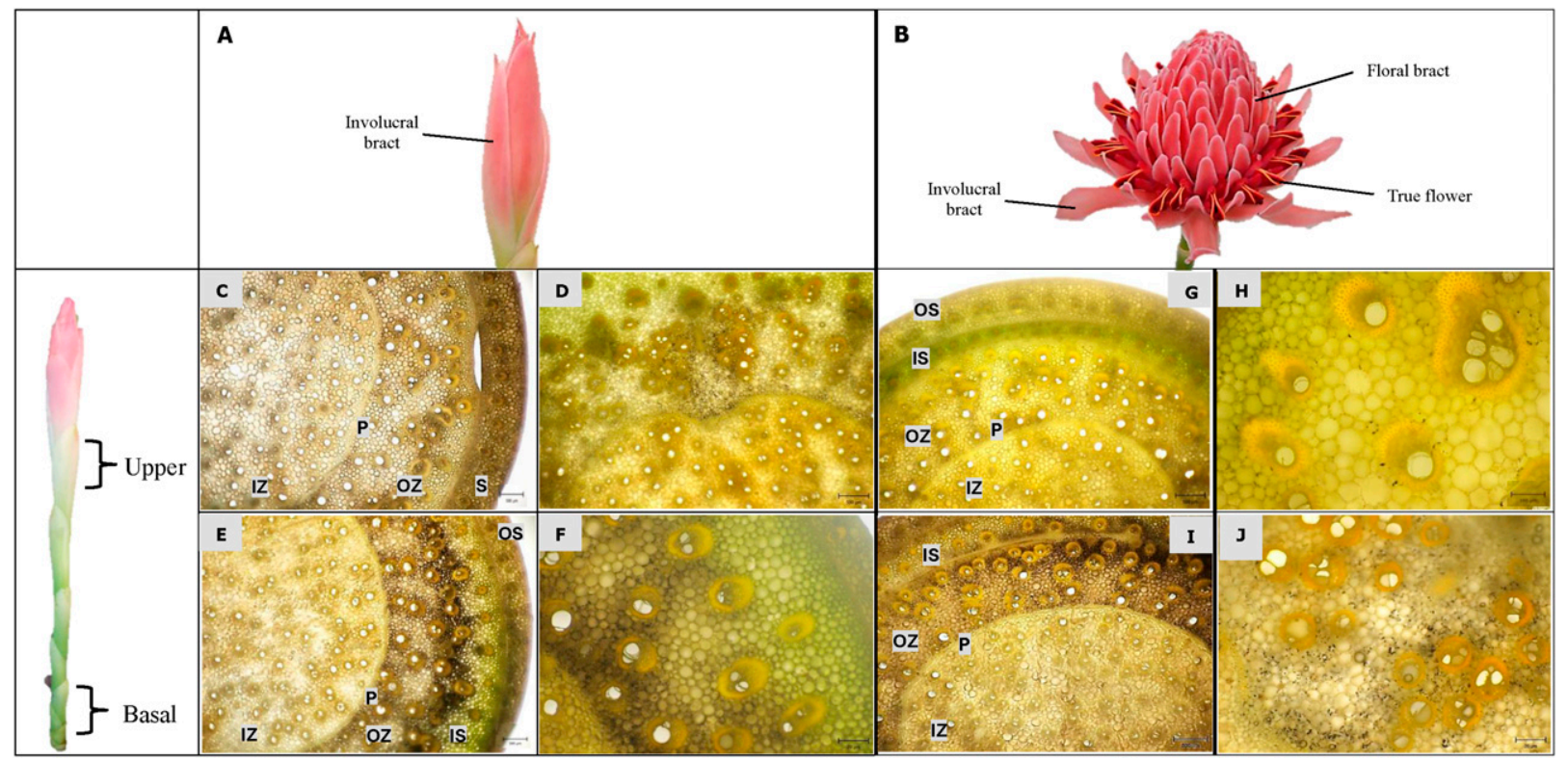

Fig. 3. Starch grains distribution in torch ginger inflorescence peduncle at (A) tight bud and (B) full bloom stages. Transverse section of the inflorescence peduncle stained with iodine solution. Tight bud stage: $(\mathbf{C})$ upper part of peduncle $($ scale bar $=500 \mu \mathrm{m})$; $(\mathbf{D})$ outer heart zone of the upper part of peduncle $(\mathrm{scale}$ bar $=$ $500 \mu \mathrm{m}) ;(\mathbf{E})$ basal part of peduncle $($ scale bar $=500 \mu \mathrm{m}) ;(\mathbf{F})$ outer heart zone of the basal part of peduncle (scale bar $=20 \mu \mathrm{m})$. Full bloom stage: $(\mathbf{G})$ upper part of peduncle $($ scale bar $=500 \mu \mathrm{m}) ;(\mathbf{H})$ outer heart zone of the upper part of peduncle $($ scale bar $=100 \mu \mathrm{m}) ;(\mathbf{I})$ basal part of peduncle $($ scale bar $=500 \mu \mathrm{m})$; $(\mathbf{J})$ outer heart zone of the basal part of peduncle (scale bar $=20 \mu \mathrm{m}$ ). The blue-black color on the peduncle section indicated the presence of starch. IZ $=$ inner heart zone; $\mathrm{OZ}=$ outer heart zone; $\mathrm{S}=$ sheath; $\mathrm{OS}=$ outer sheath; $\mathrm{IS}=$ inner sheath; $\mathrm{P}=$ pericycle ring. 
grains might indicate that photoassimilates are translocated from leaf stalk and are stored as starch at the basal part of peduncle. Plants at the vegetative stage always convert sugar photosynthates into polysaccharides and accumulate them as nutritional and energy sources (Wang et al., 2008). Therefore, the leafless peduncle is considered as storage organ of torch ginger inflorescence head.

The starch grains accumulated in the peduncle are suggested to be the primary source of soluble sugar content for the growth and development of inflorescence head. This was evidenced by the starch grains density decrease from TB to FB stage peduncle. This result indicates that starch grains are hydrolyzed and consumed as an energy source for inflorescence head development. Besides, the starch grains density decreased from the basal part to the upper part of peduncle implying the inflorescence head is a major sink. The reduction of starch grains and soluble sugar content in peduncle and involucral bracts, respectively, as the inflorescence developmental stage advanced confirmed the hypothesis on remobilization of stored carbohydrate in torch ginger inflorescence. Thus, the soluble sugar content availability during the growth and development of torch ginger inflorescence is expected to be an important factor in determining its longevity.

\section{Conclusions}

During the inflorescence development, fresh weight and respiration rate increased significantly from TB to FB stage. Water is the major constituent of the inflorescence. The significantly higher respiration rate of inflorescence accelerated stored carbohydrate depletion in involucral bracts and inflorescence peduncle. Because no ethylene was detected from the inflorescence, antiethylene agent might not be appropriate to be used as postharvest treatment. Sugar supplementation, thus, is suggested to be used as postharvest treatment for the cut torch ginger inflorescence.

\section{Literature Cited}

Carneiro, D.N.M., P.D.D.O. Paiva, L.F. Carneiro, R.D.S. Rodrigues, L.C.D.O. Lima, G.D.M.G. Dias, and R.G.A.V. Pedroso. 2014. Developmental stage and pulsing in inflorescences of torch ginger. Ornam. Hort. 20(2):163-170.

Choon, S.Y. and P. Ding. 2016. Growth stages of torch ginger (Etlingera elatior) plant. Sains Malays. 45(4):507-515.

Choon, S.Y., P. Ding, T.M.M. Mahmud, and K Shaari. 2016. Phenological growth stages of torch ginger (Etlingera elatior) inflorescence. Pertanika, J. Trop. Agr. Sci. 39(1):73-78.

Gago, C.M.L. and J.A. Monteiro. 2011. NAA and STS effects on bract survival time, carbohydrate content, respiration rate and carbohydrate balance of potted Bougainvillea spectabilis Willd. Postharvest Biol. Technol. 60:235-243.

Loges, V., A.S. da Costa, W.N.R. Guimaraes, and M.D.C.F. Teixeira. 2011. Market potential of torch ginger and beehive: Part 2. Heliconia Soc. Intl. Bul. 17(4):1-4.

Prasongchan, N., A. Jitphusa, and M. Suksawat. 2009. Evaluation of different chemicals treatments on vase life of torch ginger [Etlingera elatior (Jack) R.M. Smith], p. 304-311. In: I. Warrington, M. Grossman, W. Schaefer, K. Schaller, J. L. Silva, T. Kamimoto, S. Frusher, R. Zawadzki, T. Kiatsiriroj, P. Toedtoon, et al. (eds.). Paper presented at the International Conference on the Role of Universities in Hands-on Education 2009. Rajamangala University of Technology Lanna Press, ChiangMai, Thailand.

Reid, M.S. 1985. Ethylene and abscission. HortScience 20:45-50.

Sood, S., D. Vyas, and P.K. Nagar. 2006. Physiological and biochemical studies during flower development in two rose species. Sci. Hort. 108:390-396.

Wang, C.Y., C.Y. Chiou, H.L. Wang, R. Krishnamurthy, S. Venkatagiri, J. Tan, and K.W. Yeh. 2008. Carbohydrate mobilization and gene regulatory profile in the pseudobulb of Oncidium orchid during the flowering process. Planta 227(5):1063-1077.

Yemm, E.W. and A.J. Willis. 1954. The estimation of carbohydrates in plant extracts by anthrone. Biochem. J. 57(3):508-514. 